\title{
Lectures on ecology and environmental protection - previous knowledge and present attitudes of first year university students
}

Anna Polášková

Envigogika 2013/VIII/2- Recenzované články/ Reviewed Papers

Publikováno/Published 06 09. 2013

DOI: http://dx.doi.org/10.14712/18023061.377

\section{Abstract}

The presented article offers an insight into the environmental literacy and attitudes of young technically oriented Czech university students at a faculty of pharmacy, in preparation for non-teaching and non-ecological professional careers. At this faculty, no philosophical or emotion-based approaches to nature and wildlife are acceptable as a teaching basis, even in the case of ecology.

As an evaluation of the course 'Ecology for Pharmacists' taught in the first year, over 120 students completed - after a common credit test -an optional questionnaire. The goal was first to assess the environmental knowledge acquired by students at secondary education level and then to see their willingness to learn more about ecology and/or contemporary environmental problems.

The results showed a surprisingly low percentage of indifference. Positive relationships to environmental protection and education, although more technically oriented, prevailed. However, the level of environmental knowledge gained from their secondary education seemed to be low in most cases.

It is the opinion of the author that environmental literacy and consciousness of university students in technical fields is very important, since it is usually among middle managers and executives with technical education, that more or less environmentally friendly policies and strategies begin.

This article might contribute to a discussion about more efficient and hopefully better targeted environmental education offered by upper secondary schools and further education.

\section{Key words}

Environmental education, pharmacy-ecology, education questionnaire, university students 


\section{Introduction}

\section{Ecology at the Faculty of Pharmacy}

The subject of ecology has been taught at the Faculty of Pharmacy in Hradec Kralove (part of the Charles University in Prague), since the 1990s, when forward-thinking executives sought to redress the unsatisfactory heritage of totality and its suppression of discussion of environmental problems.

In the beginning, this involved exploring new territory. Ecology in its original form, (Odum, 1971; Begon, Harper \& Townsend, 1997) was taught by botanists from the pharmaceutical botany department as a compulsory subject for third year students, using a biologically oriented textbook (Stonawski, 1993, 1997). Since a group of foreign feepaying students were required to pass the same subjects as their Czech fellows (taught in English), similar lectures were developed for them on the basis of a somewhat broader textbook (Miller, 1987). More technology-oriented environmental problems (climate change, ozone depletion etc.) were barely mentioned.

In the following years, ecology and environmental education was formally included into the school curriculum, following the Act on the Right to Environmental Information (Act 123/1998 Coll.) and the State program of environmental education and public awareness from October 2000. Subsequently basic ecology became - or should have become - part of secondary education. It was included in the Framework Education Programmes (FEP) of schools as a cross-cutting theme approach, which is also stressed in the UN program of Education for Sustainable Development (ESD) (Dlouhá, 2011).

It seemed that the 'Ecology for Pharmacists' course was to become obsolete, especially with the creeping trend of decreasing public acknowledgement of ecology and environmentalists. Students refused to learn formal ecological laws in the third year of their studies, long after their botany course, especially when they were preoccupied with the highly demanding specialized subjects of pharmacology etc. For a few years, ecology was dropped from the study programs of the Faculty of Pharmacy. An optional course 'Monitoring of the Environment' (restricted to 30 students by the capacity of the laboratory) remained as the only environmentally oriented subject.

Only when the credit system was launched in 2007, with its complicated calculations and tactics, a need reappeared for a low-credit optional subject, so the 'Ecology for Pharmacists' course was given another chance. The botany department refused to take responsibility for this course after their recent bitter experience. Another more chemically oriented department of pharmacognosy took up the challenge and 'Ecology for Pharmacists' has been filling up a lecture hall with first year students quite satisfactorily since then.

Yet the people on both sides of the teacher's desk are different from those fifteen years ago.

\section{New demands - greater scope}

The young people in the lecture halls of these days are the computer and communications generation, open-minded but restless, inattentive, unable to listen to monotonous lectures regurgitated unchanging year in year out. It was the latter that 
induced students' protest and contributed to the temporary rejection of the subject. Today students are used to pictures, news, concise messages, examples from real life; they need 'action'. Moreover, they are usually materialistic and science-oriented; they are not used to perceiving or showing any irrational or unspecific reasoning, at least not openly. 'Talented skeptics' one would say. Only somewhere at the end of some of their essays on the environment and landscape protection might we find a note about the deeper meaning of all of the efforts towards environmental protection and sometimes even a few words about their own concern.

The teacher must adjust to the new generation of students. To stress the issue of healthcare, the course has taken on chapters dealing with environmental pollution impacts. To teach ecology (the name has not been changed, though environmentalism would be more suitable), one cannot be only a botanist: one must know some plants and animals but also a lot of chemistry and some physics and molecular biology, biotechnology and economy. The existing textbooks were either too narrow (Slavíková, 1982) or too philosophical (Moldan, 2009) or, on the contrary, too practical (Zelenka, 2007) or simple (Braniš, 2004) for the needs of this specific group. A new comprehensive monograph had to be written for this subject (Polášková et al., 2011) by several experts in different fields (a botanist, a biotechnologist, an expert on environmental analysis, a dermatologist, a physical chemist...). Since it now covers a wide range of fields, the textbook (monograph) may be useful for a wider group of readers; only a few specifically pharmaceutical aspects are included. The main goal was to fill in the gaps in the environmental literacy of students who feel they are lacking general education in the subject.

However, a textbook is not good enough when preparing lectures; all information must be fresh and interesting, referring to the continuously changing legislation and its impacts.

There is one beacon of hope that helps to overcome the challenges described above. Most of the students of the highly selective faculty of pharmacy probably belonged to the top academic cohort of their secondary school classes, are from families which regard education highly, and may be the fourth generation of pharmacists in the family. They are likely to become influential members of society and each small improvement of their environmental conscience and education may have substantial impacts on their later decisions. And in addition, their well hidden warm relationships to the charms of the landscape of their home country, nurtured by to parents and previous teachers, occasionally come close to the surface.

\section{Space for students" opinions}

As the present teacher cannot continue in this role and the future fate of the subject has become endangered again, a rather informal investigation, a kind of marketing study, was accomplished via questionnaires completed by students to investigate the importance of components and methods offered in the subject and the response from the point of view of the 'consumer'- the student.

The results indicated a positive response of the students and after presentation to the dean and the scientific council of the faculty it has helped to preserve the subject 'Ecology for Pharmacists' in the Pharmaceutical faculty program, at least for next year. 
As a by-product of the investigation, information on the entry knowledge about ecology and environmental protection brought by students from their secondary education schools may provide evidence for the need to improve environmental education schemes.

Frankly speaking, most of the information transmitted to these university students during the ecology lectures are facts that every moderately educated person should gain at the latest during secondary education. In some European countries, knowledge and consequently also interest in environmental issues seem much higher compared to those in the Czech Republic. In this country, efforts of a concerned part of our public to stop assaults on the environment are often satirized pointing out the low level of factual knowledge.

Information based on solid data to ascertain how best, if at all, to continue teaching the subject of ecology at the faculty was ultimately necessary. Some academic voices kept speaking against the subject as a whole.

\section{Methods}

In this section, the characteristics of the students involved in the research, teaching methods used at the faculty and the design of the study are described in brief. In this pilot and special-purpose study, no precise statistics were applied, as otherwise recommended in pharmaceutical (Rowe, 2007) or proper 'envigogics' (Dvořačková \& Ryplová, 2012) trials. Only a simple version of descriptive statistics has helped to choose the relevant points. The group of students involved in the study was relatively large (124 respondents) and represented a reasonably homogeneous selection of students shortly after finishing their secondary schools.

\section{Characteristics of students involved in the study}

Each September, more than two thirds of all of the first year students and also some second year students (altogether over 200 people) of the Faculty of Pharmacy in Hradec Králové enroll for the optional 'Ecology for Pharmacists'. The author would guess - in accordance with the well-known "credit system strategy" - that they consider this course to be the easiest way to acquire two credits, after their recent secondary ecological education, culminating with their A levels. At the grammar schools where most of them studied, the ecological niche and similar 'marginalities' represented only a small part of their biology lessons (VUP, 2007).

As for the background of other students, only a small number of them come from special ecology oriented schools, another minor group of girls have finished secondary healthcare schools with no ecology taught at all (these schools are too busy teaching specialized subjects). In recent years, quite a lot of students are Slovaks. The secondary school systems in Slovakia and the Czech Republic are similar.

Students from grammar schools as well as those who have never attended any ecology lesson may think at the beginning the same way as the majority of our population - that ecology is something like talking about ethical principles of wildlife protection and separation of waste. From the students' sighs over the wide range of lecture topics (and credit test questions), the author estimates they expected that the subject would be merely a repetition of trivial rules and facts they know and that acquiring these credits would be easy. 


\section{Content of the subject and methods of teaching}

The author has encountered many times the obvious principle that an illustrative teaching with a lot of active student participation is especially useful when teaching an optional subject. The aim is to show students first of all the practical impacts of ecological and environmental knowledge, professional environmental protection and those responsible for it. After a short general introduction, an excursion to a nearby valuable and threatened part of the city surroundings takes place (see Fig. 1). Here, young educated people, professionals from the Agency for Nature and Landscape Protection, explain why and how they have to resist numerous developers' pressures and threats, using genuinely ecological knowledge gained at school.

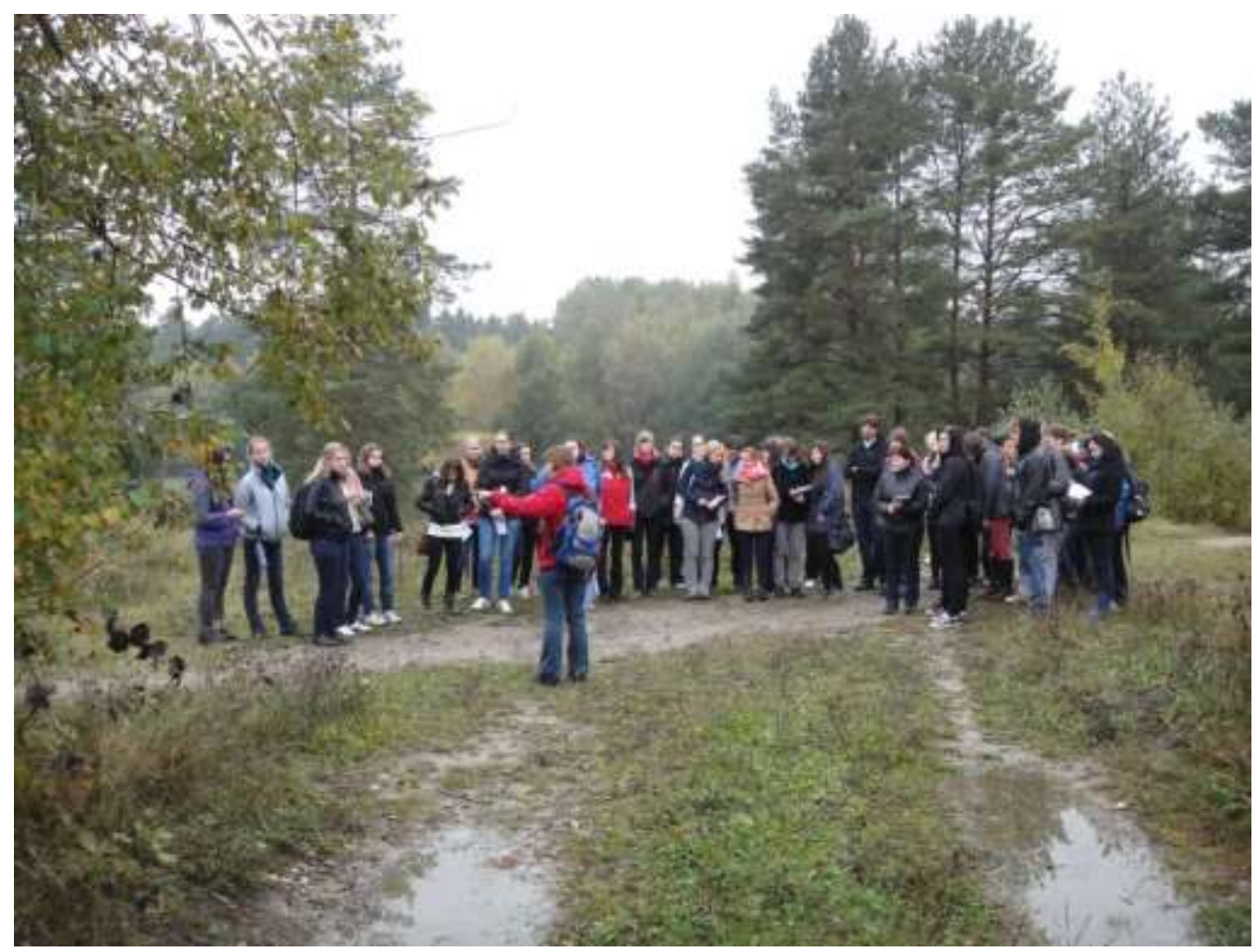

Fig. 1: Ecology and environmental protection in practice (October 2012): an excursion of one of four groups of pharmacy students to the Natura 2000 Site of Community Importance (SCI). SCI Plachta is situated very close to the city and professionals from the Agency for Nature Conservation and Landscape Protection (including Dr. Blanka Mikátová in the photograph) are frequently in a disagreement with developers and their city-hall advocates.

The remaining lectures cover a wide range of ecological and environmental topics, from ecological laws, through food chains, biotechnology, air and water pollution, to the chemicals and wastes legislation and some basic toxicology. All these topics (listed in Appendix 1) must be covered in as little as 12 lectures. 
To support active participation, students are asked to prepare a short review dealing with landscape or species protection or an environmental pollution problem. A wide range of possible topics are at their disposal; they can also choose any other environmental problem they are especially interested in. Appendix 2 shows only several of over 100 topics that students decided to review in the academic year 2012-13.

As it turns out, all students have very good training from secondary schools in how to prepare presentations. Now, during the ecology lectures, they are invited to try their talents and show and comment their presentations from the teacher position.

A properly completed semestral work (essay) represents a substantial part of the credit demands.

Public presentation is not compulsory (some students are very shy) but is rewarded with a small point of advantage.

When the time of the final evaluation comes, a common multiple choice credit test is taken by all students who have written or presented their semestral work. As a clear guideline - to see what is necessary to know for the test - students find the test topics in the Study materials (see Appendix 1).

All necessary explanations to the subject matter, relevant data and facts as well as the original references can be found in the textbook (Polášková et al, 2011).

\section{Methods for evaluation of the knowledge acquired - the credit test}

First, the multiple choice credit test 2012-13 was evaluated. The final score for the credit consisted of points for participation in the excursion, the semestral work, the presentation, and the test. At the end of the credit test, students answered a special question about the ratio of their entrance (from secondary school) and their final (after finishing the subject of Ecology) knowledge on ecology and environmental issues. Before receiving the credit, each student had the chance to see his or her test, to discuss the mistakes and to comment on the semestral work.

\section{Methods for evaluation of attitudes - questionnaire investigation}

After having written the credit test, all students were given a special, optional questionnaire. It was completely anonymous and students were told to feel free to express their real thoughts. Questions covered various aspects of the subject, its content and methods. Students were informed that in this way they could help younger student who would study the subject in following years.

The advantage of this approach was that the real thoughts of students would be made clear. A slightly provocative form of some question was chosen for the students to make them feel completely free to write anything. Of course, some malicious remarks were also expected.

The otherwise common questions about teacher quality (used in many questionnaires and infused with personal sympathy or antipathy) were avoided since it was assumed this information would logically emerge from the overall evaluation. 
The disadvantage of the anonymous form was that some relationships could not be evaluated, such as the coincidence between bad test results and a bad subjective rating of the subject; neither type of school was connected with very good results, nor on the other hand, with an insufficient level of environmental education.

\section{Results}

In the academic year 2012-2013, 207 students enrolled for the course 'Ecology for Pharmacists'. A total of 135 students submitted their semestral work and wrote the test on the prescribed date. About $90 \%$ successfully passed the first trial.

Of the remaining enrolled students, some decided to attend other optional lectures (there are students who enroll for all possible optional subjects) or to take the test and gain their credits later, which is possible before the end of the academic year.

A total of 124 students out of 135 agreed to complete the optional questionnaire (some excused themselves for a lack of time).

\section{Active participation in the program and the level of knowledge - the teacher"s point of view}

In regard to the semestral work, most students wrote more than the necessary 3-5 pages.

They wanted to share the new and/or interesting information they had just discovered. Finally, many students seemed very pleased they could refer to places or themes they liked; their public presentations were not as derided as one would expect at their age. Both the students as the 'lecturers' and the audience took these presentations very seriously. Especially when "a smaller protected landscape area close to my home or heart" (according to the assignment) was described, surprisingly, they now seemed to put their heart into it.

On the basis of the test results, some common conclusions could be inferred without a precise numerical evaluation of the points. Most of the students passed successfully, possibly due to the rather mild conditions set in advance.

The author would like to mention that it was not possible to thoroughly explain all the different and complicated topics within 12 optional lectures = expected 28 hours of students' involvement (themes of which are shown as "test topics", see Appendix 1), particularly in those cases where the students had not been acquainted with the topics beforehand.

Theoretically, the students should have some knowledge from their secondary education. For instance, the Framework Education Programme for Secondary General Education states that students should "evaluate the problems of endangered plant species and possible ways of protecting them, use basic ecological terms correctly, explain basic ecological relationships" etc. (VUP, 2007).

In relation to these topics, the following observations have been made based on the frequent mistakes and missing answers to the test questions: 
- Biodiversity and its protection at the national and international level (Brožová, 2004): Hardly anybody has previously heard about CITES, which may have undesirable consequences even in their future pharmaceutical practices (Stejskal \&Vilímková, 2005). Categories of wildlife protection, red lists (Procházka, 2001), rainforest and other rare medical plants (Hawkins, 2008), Fair Trade - all of these were obviously new things to many students.

- General problems of mankind: World leaders strive to protect mankind from poverty, thirst, hunger, diseases, illiteracy; nobody has probably told the students about Millenium Development Goals (UN, 2007).

- Biotechnology: The students previously heard very little about the mechanisms of biotechnology (Gerald\& Dill, 2005), and about important drugs manufactured by genetic engineering methods (Fusek, Kas \& Ruml, 2008). They knew nothing about the many enzymes we consume every day in our baked products, yoghurts, cheese, soft drinks and spirits that have been produced by genetically engineered microorganisms and that must be included in the Community Register of GM food and feed. They may admire the "heroism" of some Czech scientists who, in a similar way to top politicians, snigger at the "amusing" preliminary precaution principle of the EU (Biologické centrum AV ČR, 2009). Even here, some differentiation should be made between superstition, rumour and the scientific reality (SZU, 2003); for example, that the enzymes gained from genetically modified microorganisms (GMM) are usually harmless, unlike some other food additives and contaminants (Malír, Ostrý, Grosse et al., 2006). In addition, the basic principles of organic farming were understood in a somewhat rudimentary way (Dvorský).

- Water pollution: Even the simplest facts about water hardness and water eutrofication had in some cases clearly been forgotten already by the students. (Kožíšek, 2006; Kočí, Burkhard \& Maršálek, 2000). A similar situation was observed with the topics on cyanobacteria, gains and losses due to tap water chlorination, etc.

- Regarding the rather wide topic of air pollution, many students lacked knowledge on ozone formation and depletion, UV-B radiation risks and benefits (Vaníček, Janouch \& Ettler, 2004), and about the everyday consequences of ionizing radiation and radon pollution (Ullman) etc. Common air pollutants like dust particles (PPM) and their constant overextended levels that cause a substantial deterioration of our life quality and are reported on the daily basis in the media were also not particularly well-known to most students (Weinmayr, Romeo, De Sairo et al., 2010). The same is true of greenhouse gases and legislation on climate change prevention (the Act on the Protection of the Atmosphere. 86/2002 Coll.).

- Every day, dangerous chemicals flood our world and cause many hormonal, reproductive and other health problems. Enormous international efforts have been made to define criteria for their harmful effects and to restrict the most dangerous chemicals, e.g. via REACH legislation. It is unlikely that many of these problems have penetrated through secondary school walls (based on the lack of knowledge of the students) (ECHA).

Perhaps the students have heard about all these things, perhaps this information has been only too thoroughly integrated into many different subjects, in which case there is some sense in digging it out and refreshing it. It seems that if only the secondary school 
environmental part of the curriculum was more technically and practically oriented, then 'Ecology for Pharmacists' would be unnecessary. To date, however, there are too many highly educated specialists and technicians who are not ashamed of knowing next to nothing about the crucial environmental problems of our world.

\section{The level of entrance knowledge - students" point of view}

Sometimes, the students seemed surprised during the lectures by facts that should be well-known recently (thanks to the FEPs etc.) and that are often discussed in the media, albeit in a distorted way in some of them (bio- and nanotechnologies, climate change, air pollution, water eutrophication, food chain pollution...). Therefore, a logical question to ask is whether the secondary education curriculum should include a higher level of integration of these facts.

To get information on the students' entrance environmental/ecology knowledge, a simple question was asked of the students at the end of their credit tests: "What percentage of the knowledge on ecology taught here had you already acquired at secondary school?"

The results show the subjective estimations of students (Tab.1.and the Fig. 1)

Tab.1: Environmental and ecological knowledge acquired at upper secondary schools

\begin{tabular}{|l|l|l|l|l|l|l|}
\hline previous knowledge & $0-10 \%$ & $11-20 \%$ & $21-30 \%$ & $31-40 \%$ & $41-50 \%$ & $>50 \%$ \\
\hline number of responses & 32 & 18 & 33 & 11 & 13 & 7 \\
\hline & & & & & & \\
\hline
\end{tabular}

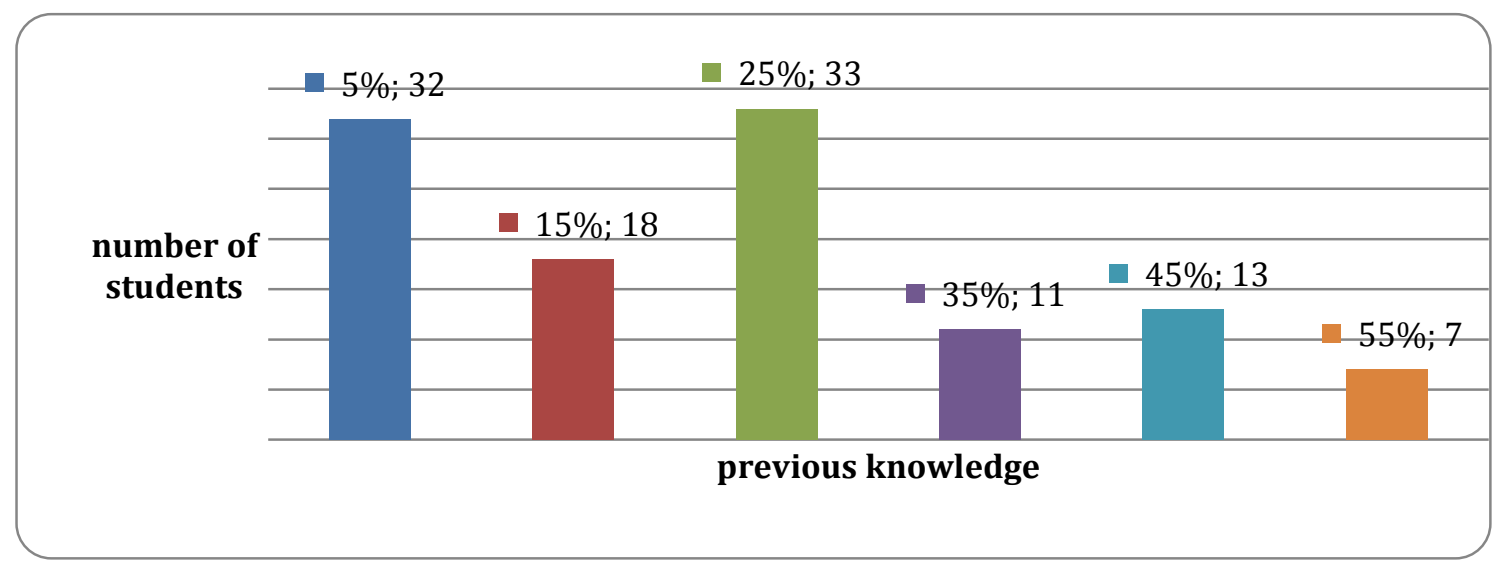

Fig.1: Environmental and ecological knowledge acquired by first year pharmacy students at upper secondary schools, respective columns refer to the Table 1 
Without any precise evaluation, the chart shows that usually less than $30 \%$ of the desired environmental knowledge had been acquired at upper secondary schools (see Fig.1 and Tab.1).

As mentioned in Methods above, before obtaining the credit, each student had the chance to talk individually with the teacher about the test and their semestral work.

Naturally, their declared and surprisingly low level of the previously acquired environmental knowledge was also often discussed. The explanation of many students was: "it is true, ecology was usually taught as the last part of biology, just before the leaving certificate exam, and there was not enough - if any - time left for it. Ecology was reduced to a few definitions that were necessary (and sufficient) to learn."

The result was, for example, that nearly all students were acquainted with the definition of the environmental niche and almost nobody was able to explain, for instance, what 'the niche of an owl' means and why this species is endangered (which was sometimes one of the credit test questions).

\section{Evaluation of the subject -students' point of view}

The optional questionnaire presented to students was by no means a part of pedagogical scientific research. It was simply an attempt to acquire relevant and accurate information on the usefulness of the individual parts of the subject of 'Ecology for Pharmacists' (what to stress and what to omit in the syllabus and how to improve teaching methods in future years). The main goal was, however, to justify the existence of this course at the university level, when some people pointed out its redundancy after the implementation of Education for Sustainable Development (ESD) into secondary education curricula.

Table 2 shows the topics discussed in the subject and students' assessment of their usefulness and/or attractiveness. 
Tab. 2: The questionnaire and its results. Students were given 27 questions and asked to circle those they considered relevant to themselves. The results in the following table show the percentage of statements circled from the total number of returned responses.

\begin{tabular}{|c|c|c|c|}
\hline & $\begin{array}{l}\text { Respondents to the evaluation of 'Ecology for } \\
\text { Pharmacists' }\end{array}$ & 124 & $\begin{array}{c}100 \\
\%\end{array}$ \\
\hline & "circle the statements that corresponding best to your opinion" & Yes: & \\
\hline 1 & a relatively easy possibility to gain 2 credits & 27 & $22 \%$ \\
\hline 2 & too much work for 2 credits & 26 & $21 \%$ \\
\hline 3 & only repeating facts well known from secondary school & 2 & $2 \%$ \\
\hline 4 & $\begin{array}{l}\text { quite useful information about possible environmental } \\
\text { impacts }\end{array}$ & 107 & $86 \%$ \\
\hline 5 & filling in the gaps in secondary education & 75 & $60 \%$ \\
\hline 6 & useless general talking & 2 & $2 \%$ \\
\hline 7 & presentations: embarrassing show in front of fellow students & 2 & $2 \%$ \\
\hline 8 & useful training for public presentations & 50 & $40 \%$ \\
\hline 9 & $\begin{array}{l}\text { Semestral work: motivation for deeper study of a site or a } \\
\text { problem I had been interested in anyway }\end{array}$ & 43 & $35 \%$ \\
\hline 10 & I was quite surprised by some information & 105 & $85 \%$ \\
\hline 11 & I have not been enriched by this mixture of knowledge & 0 & $0 \%$ \\
\hline 12 & no pity if this subject is cancelled & 3 & $2 \%$ \\
\hline 13 & excursion: quite an interesting meeting with ecologists & 87 & $70 \%$ \\
\hline \multirow[t]{2}{*}{14} & excursion: waste of time & 7 & $6 \%$ \\
\hline & Lectures that provided nothing for me & & \\
\hline 16 & general ecology & 42 & $34 \%$ \\
\hline 17 & systems of nature protection & 12 & $10 \%$ \\
\hline 18 & biotechnology & 13 & $10 \%$ \\
\hline 19 & air pollution problems & 1 & $1 \%$ \\
\hline 20 & water pollution problems & 2 & $2 \%$ \\
\hline \multirow[t]{2}{*}{21} & chemistry as an environmental burden & 11 & $9 \%$ \\
\hline & Lectures that attracted my attention & & \\
\hline 22 & general ecology & 19 & $15 \%$ \\
\hline 23 & systems of nature protection & 35 & $28 \%$ \\
\hline 24 & biotechnology & 76 & $61 \%$ \\
\hline 25 & air pollution problems & 67 & $54 \%$ \\
\hline 26 & water pollution problems & 62 & $50 \%$ \\
\hline 27 & chemistry as an environmental burden & 64 & $52 \%$ \\
\hline
\end{tabular}

Significant answers (over $25 \%$ of respondents) are printed in bold letters. 
Only answers confirmed in the questionnaire by more than $25 \%$ of respondents were considered significant (bold). This is in accordance with the simple descriptive (quartile) statistics often used for questionnaire investigations. The lower quartile may be excluded as insignificant.

As seen from the significant answers, students felt unsatisfactorily informed about the problems of modern technologies and the impacts of environmental pollution. On the other hand, general ecology is probably already included in secondary school education programmes - the question is, why does it then not evoke more interest?

\section{Evaluation of attitudes - students" point of view}

In this subject, not only the facts and practical impact of ecological knowledge and environmental protection play a role. For sustainable development, no less important is the attitude of people to environmental problems, to their region and its wildlife, etc. Several questions in the questionnaire dealt with these aspects. Table 3 shows how students feel about the impact of the teaching of ecology.

Tab. 3: Overall attitude as a result of learning in 'Ecology for Pharmacists'

\begin{tabular}{|l|c|c|}
\hline What was the change? & students & \\
\hline $\begin{array}{l}\text { 1...my level of knowledge and interest in ecology and } \\
\text { environment protection has slightly improved }\end{array}$ & $\mathbf{3 9} \%$ \\
\hline $\begin{array}{l}\mathbf{2} \text {... my level of knowledge and interest in ecology and } \\
\text { environment protection was and remains slightly positive }\end{array}$ & $\mathbf{7 2}$ & $\mathbf{5 8 \%}$ \\
\hline $\begin{array}{l}\text { 3... I am as indifferent to ecology and environment protection as } \\
\text { before }\end{array}$ & 5 & $4 \%$ \\
\hline $\begin{array}{l}4 \ldots \text { my opinion on ecology and environment protection was and } \\
\text { remains negative }\end{array}$ & 0 & $0 \%$ \\
\hline
\end{tabular}

The results of this part of the questionnaire are highly optimistic - even if strongly positive expressions (like "a greatly improved" attitude to ecology) were avoided on purpose, based on the psychology of this age group. Very positive language is rather uncommon when it refers to any kind of school.

In spite of a relatively low level of knowledge in many cases, the main goal of the subject, the cultivation of an environmental consciousness among this young generation, has been achieved. 


\section{Conclusions}

Some important conclusions can be made on the basis of the evaluation of students' attitudes to the subject of ecology, including teaching programmes and methods. It is nevertheless important to bear in mind that, as already mentioned above, no particularly precise analytical methods (such as a statistical analysis of data) could be used from the multiple choice test results and from the questionnaire. The most important outcomes are as follows:

1. First of all, the results of the questionnaires are interesting, some of them seem surprisingly positive and inspiring, and they have provided the faculty with good feedback prior to further planning of the subject of 'Ecology for Pharmacists'.

2. There are some gaps in the secondary education system (in the countries examined, i.e. the Czech Republic and Slovakia), so that the students seem to have incomplete information about the environmental and health impacts of air and water pollution, biotechnology, or deliberately used and lightly controlled dangerous chemicals. And they would like to know more.

3. Only some secondary schools seem to pay attention to the system of wildlife and landscape protection in these countries and even less to international regimes. Meeting professionals and seeing their enthusiasm may change the indifferent attitudes of students. One's own experience with the thorough exploration of a small protected area seems even more influential.

4. Teaching the young adult 'talented skeptics' is a difficult and demanding job and the teacher should let students mimic the active lecturer role -give them their desired 'action'.

5. 'Ecology for Pharmacists' is not at all a highly scientific subject. It aims only at covering a moderate range of environmental knowledge that a moderately educated European citizen should possess, especially in the field of environmental pollution, new technology impacts, and international efforts to mitigate the negative consequences of our civilisation. Students admit they get more than a half of this important information as late as their studies at university, at the age of nearly twenty.

6. And last but not least: Our students will become managers, research workers or pharmacists. All of them will make decisions and perform activities that include the wide use of chemicals with direct health and environmental impacts. The amounts of pharmaceuticals, their precursors, side products, metabolites, solvents etc. entering our world from various stages of medicinal preparative lifecycles cause great concern (VUP, 2007). It is no surprise that pharmaceutical companies belong to the worst polluters in the region, not to mention incorrect disposal at the household level, community wastewaters, etc. Desired greener pharmacy can only be accomplished with greener pharmacists.

\section{Acknowledgements}

The author, who is used to preparing primarily technical publications, would like to thank the editor, Dana Kapitulčinová, for her many good ideas and suggestions on how to make this text more understandable and accessible for readers from non-pharmaceutical and non-technical backgrounds. 


\section{Appendix 1:}

\section{Test topics - 'Ecology for Pharmacists':}

1. Sustainable development, world summits and activities towards sustainable development, Rio de Janeiro Earth summit, Millenium development goals

2. Food chains, food webs, food (energy) pyramid

3. Biological amplification, bioaccumulation of pollutants

4. Autecology: environmental factors - tolerance, stress, natural selection

5. Homeostasis, poikilothermic and homoiothermic organisms, ecology laws, plant classification according to the optimum of tolerance

6. Demecology - positive and negative interspecific relationships, allelopathy, mycorrhiza

7. Population dynamics, carrying capacity, ecological niche

8. Synecology - development of ecosystems (succession, zonality)

9. Most threatened world biomes, red lists of endangered species (categories), biodiversity.

10. Some examples of world wildlife and biodiversity protection (UNESCO Man and biosphere, Earth summit Rio de Janeiro...).

11. European system of NATURA 2000 (2 parts, habitats, species protection)

12. International trade in endangered species, CITES convention, goals and principles, examples, consequences for pharmacists

13. Invasive species - examples, impacts

14. Biotechnology - the history and variety of applications, examples of semisynthetic production, bio(phyto) remediation, cell (plant) cultures

15. Basic procedures of genetic modification: vectors, marker and reporter genes, important products of genetically modified microorganisms

16. GM plants, most frequent modifications - goals and principles

17. GMO - definition by Cartagena protocol, precautionary principle, rules

18. Genetic engineering in medicine, genetically modified animals, GMO in food (labeling)

19. Organic farming - principles, rules about application of chemicals and GM products, biological plant protection

20. Food and feed safety, European rules and codes for food additives, E-codes (numbers), examples of suspect additives

21. Food contaminants - the most frequent and most dangerous ones, rapid alert system, residual analysis, problems of pesticides

22. Drinking water - sources, waterborne diseases, drinking water treatment - positives and negatives of chlorination, indicators of water quality (nitrates, trihalomethanes, water hardness)

23. Surface waters - eutrophication, reasons and consequences, cyanotoxins, waste water treatment, residual contamination (drugs, hormones) 
24. Air quality monitoring and indicators, common air contaminants, problems of PM, indoor air contaminants

25. Smog situations - winter smog and acid rain, summer smog and tropospheric ozone sources, health impacts, phytotoxicity

26. Stratospheric ozone - Dobson units, UV radiation kinds $(A, B, C)$ and roles, health impact of ozone layer depletion, ozone depleting substances, Montreal protocol

27. Climate change, greenhouse gases, Kyoto protocol

28. Ionizing radiation - deterministic and stochastic impacts, main environmental sources, radon occurrence and monitoring

29. Toxins in the environment - risk assessment, dose-response relationship, toxicity (LD), safe levels of additives and contaminants

30. The most dangerous toxins in the environment - POPs: dioxins, PCBs, Stockholm convention, bioindicators of pollution, biocides and pesticide types.

31. New European chemical legislation REACH: substances of very great concern - criteria for evaluation, timing of REACH introduction, examples of SVHC substances

32. Late impacts of xenobiotics, aromatic hydrocarbon sources and impacts, phthalates in the environment, hormonal disruptors.

33. Waste - categories, waste from pharmacies disposal rules, safe removal (combustion or deposits - negative impacts comparison)

34. Nanotechnology- applications, possible environmental impacts 


\section{Appendix 2 : Some examples of the topics of semestral works chosen by students (2012/13)}

\begin{tabular}{|ll|}
\hline 1. & Genetically modified organisms in medicine \\
\hline 2. & Geoengineering and climate protection \\
\hline 3. $\quad$ Peat-bogs in the Jizera mountains \\
\hline 4. $\quad$ Cyanobacteria and the struggle for cleaner water reservoirs \\
\hline 5. $\quad$ Electromagnetic smog and cell-phones \\
\hline 6. $\quad$ A Paradox Ambystoma mexicanum \\
\hline 7. $\quad$ Dangerous aspects of shale gas extraction \\
\hline 8. $\quad$ Collection of medicinal plants and nature protection \\
\hline 9. $\quad$ Highways and animal overpasses \\
\hline 10. NNR Rejvíz -Large and Small Peat-Moss Lakes \\
\hline 11. Pesticides around us - possibilities of reducing the risk of intake \\
\hline 12. The forest park of Šeptouchov \\
\hline 13. Medicinal plants in organic farming \\
\hline 14. Chlorella vulgaris \\
\hline 15. Water contamination by hormonal medical drugs \\
\hline 16. NM Meanders of Struha \\
\hline 17. Rescue stations for injured wild animals \\
\hline 18. NR Sutice \\
\hline 19. Legislation - aspects of the growing of Cannabis and Papaver \\
\hline 20. Toxicity tests in cosmetics \\
\hline 21. Pros and cons of eating fish \\
\hline 22. Traditional medicine and CITES \\
\hline 23. Food fortification in the U.S. and in Europe \\
\hline 24. Food safety - RASFF \\
\hline
\end{tabular}

\section{References}

- Begon, M., Harper, J., \& Townsend, C. (1997). . Olomouc: Vydavatelství Univerzity Palackého.

- (2009). : Biologické centrum AV ČR. Retrieved from http://www.bc.cas.cz/en/MOBITAG.html

- Braniš, M. (2004). . Praha: Informatorium. 
- Brožová, J. (2004). . Praha: MžP.

- Dlouhá, J., Adomssent, M., Barton, A., \& Fadeeva, Z. (2011). ., 19(9-10), 1144-1145. Retrieved from http://linkinghub.elsevier.com/retrieve/pii/S0959652611000436 http://dx.doi.org/10.1016/j.jclepro.2011.02.002

- Dvořáčková, S., \& Ryplová, R. (2012). ., 7(3), Retrieved from http://www.envigogika.cuni.cz/index.php/Envigogika/article/view/77

- Dvorský, J. . . . Retrieved from http://www.zeraagency.eu/dokumenty/007005/v_4_dvorsky_ez.doc

- Eea, (2010). . : EEA. Retrieved from http://www.eea.europa.eu/publications/pharmaceuticals-in-the-environment-result-ofan-eea-workshop

- European_Chemicals_Agency", .. : European Chemical Agency. Retrieved from http://echa.europa.eu/cs/regulations/reach/legislation

- Fusek, M., Kaš, J., \& Ruml, T. (2008). . Praha: Vydavatelství VŠCHT.

- Gerald, M., \& Dill, G. M. (2005). ., 61(3), 219-224. Retrieved from http://toxnet.nlm.nih.gov/cgi-bin/sis/search/r?dbs+hsdb:@term+@rn+56-40-6 pmid:15662720 http://dx.doi.org/10.1002/ps.1008

- Hawkins, B. (2008). .,

- Kočí, V., \& Burkhard, J., Maršálek, B., (2000). . Paper presented at Eutrofizace 2000, Praha. Retrieved from http://www.vscht.cz/uchop/ekotoxikologie/kategorie/eutro tisic.pdf

- Kožíšek, F. (2006). . Paper presented at Int.Symp.on Health Aspects of Calcium nd Magnesium in Drinking Water, Baltimore.

- Malir, F., Ostry, V., Grosse, Y., Roubal, T., Skarkova, J., \& Ruprich, J. (2006). . , 50(6), 513-518. Retrieved from http://doi.wiley.com/10.1002/mnfr.200500175 http://dx.doi.org/10.1002/mnfr.200500175

- Miller, G. T. Jr, (1987). . Belmont: Wadsworth Publishing Company.

- Moldan, B. (2009). . Praha: Karolinum.

- Odum, E. P. (1971). . Philadelphia: W. B. Saunders Comp.

- Polášková, A., \& al, (2011). . Praha: Karolinum.

- Procházka, F. (2001). . Praha: Praha: Príroda.

- Rowe, P. (2007). . Chichester: Chichester: John Wiley.

- Slavíková, J. (1982). . Praha: UK.

- Stejskal, V., \& Vilímková, V. (2005). . Praha: Linde.

- Stonawski, J. (1993). . Praha: Karolinum. 
- SzÚ, (2003). Př́datné látky (aditiva) v potravinách. Praha: VVP:ADIT/2003/1 deklas.. Retrieved from http://www.chpr.szu.cz/vedvybor/dokumenty/

- Ullman, V. . Detekce a aplikace ionizujícího záření. . Retrieved from http://astronuklfyzika.cz/JadRadMetody.htm

- Un, (2007). The Millennium Development Goals Report. 2007.. : UN. Retrieved from http://www.un.org/millenniumgoals/pdf/mdg2007.pdf

- Vaniček, K., Janouch, M., \& Elller, K. (2000). UV index for the public. Praha: CHMI.

- Vúp, (2007). Framework Education Programme for Secondary General Education (Grammar Schools). Prague: VúP.

- Weinmayr, G., Romeo, E., De, M., Sario, Weiland, S. K., \& Forastiere, F. (2009). . , 118(4), 449-457. Retrieved from http://ehponline.org/article/info:doi/10.1289/ehp.0900844 pmid:20064785 http://dx.doi.org/10.1289/ehp.0900844

- Zelenka, J. (2007). Ekologie a environmentalistika. Hradec Králové: Gaudeamus, UHK.

\section{RNDr. Anna Polášková}

Charles University in Prague

Faculty of Pharmacy in Hradec Králové

Department of Pharmacognosy

Heyrovského 1203, 50005 Hradec Králové

e-mail: anna.polaskova@faf.cuni.cz

The author is a bioanalyst who teaches the 'Ecology for Pharmacists' and the 'Monitoring of the Environment' courses at the Faculty of Pharmacy in Hradec Králové. 